\title{
Evaluation of Co-compost of Oil Palm Empty Fruit Bunch and Cow Dung as Fertilizer in Oil Palm Nurseries
}

\author{
Olugbenga O. AdeOluwa ${ }^{1}$
}

(C) Uganda Martyrs University

\begin{abstract}
Oil palm empty fruit bunch (EFB) is one of the readily available crop residues that can serve as cheap organic fertilizer source for crop. EFB-cow dung composts (EFB: cow dung ratios of 100:0, 80:20, 60:40, and 0:100) pre-treated by soaking in water, unsoaked and sole cow dung (all on dry weight basis) were incubated in an Alfisol under laboratory conditions for 10 months. These treatments were also used to raise oil palm seedlings in the nursery. Nutrient release pattern of unsoaked EFB: cow dung (60:40) was significantly $(\mathrm{p}<0.05)$ better than other EFB compost treatments. Correlation coefficient $(\mathrm{r})$ between phosphorus released and ECEC with time of incubation were 1.00 and $0.98(\mathrm{p}<0.01)$ respectively. Unsoaked EFB cow dung $(60: 40)$ was as effective as mineral NPKMg fertilizer in enhancing plant dry matter accumulation and nutrient uptake.
\end{abstract}

Keywords $\cdot$ Oil palm $\cdot$ Incubation $\cdot$ Organic fertilizers

Evaluation du Fumier de Régimes Sans Fruit de l'Huile de Palme et de la Bouse comme Fertilisant dans les Pépinières de l'Huile de Palme · Résumé - Le Régime Sans Fruit (RSF) de l'huile de palme est une des plantes résiduelles très disponibles qui peuvent servir de source du fertilisant organique a moindre cout. Les fumiers de RSF-bouse (taux RSF : bouse de $100: 0$, $60: 40$, et $0: 100$ ) traités au préalable par un trempage dans l'eau, sans trempage, et finalement seule la bouse (en poids net) ont été incubés dans l'Alfisol dans les conditions de laboratoires pour 10 mois. Ces traitements ont été utilises pour élever l'huile de palme dans les pépinières. Le relai de nutritifs du fumier sans trempage RSF : bouse $(60: 40)$ était significativement mieux $q u$ 'autres fumiers RSF de traitements $(p<0.05)$. Le coefficient de corrélation $(r)$ entre le phosphore produit et l'ECEC avec le temps d'incubation étaient de 1.00 et $0.98(p<0.01)$ respectivement. Le taux du fumier RSF sans trempage: bouse $(60: 40)$ était aussi effectif que le fertilisant minéral $N-P-K-M g$ en renforçant l'accumulation de matières sèches dans la plante et la valeur nutritive. Mots Clé $\cdot$ Huile de Palme $\cdot$ Incubation - Fertilisants organiques

\section{Introduction}

Inorganic fertilizers are becoming too expensive for majority of farmers in many parts of the tropics. This situation has triggered the problems of insufficient fertilization and soil nutrient mining in many farms owned by poor resource farmers. Production in many farms has been on the decline due to the inability of the agricultural soils to meet up with crops' demand for essential nutrients. The desire of the Government of many countries is to revitalize agricultural productivity

\footnotetext{
${ }^{1}$ University of Ibadan, E-mail: adeoluwaoo@yahoo.com
} 
of their countries. Nigerian government for example believes that once again, major foreign income would be earned through agriculture in the future. For this target to be realised, agricultural production should be backed up with provision of cheap and readily available fertilizers to sustain crop production.

Oil palm (Elaeis guineensis L Jacq.) is one of the crops of national economic importance in Nigeria (AdeOluwa and Adeoye, 2008). This plant is reported the most productive oil producing plant in the world, with one hectare of oil palm producing between 10 and 35 tonnes of fresh fruit bunch (FFB) per year (von Uexkull, 1992). The crop produces an average of about $6 \mathrm{t}$ oil ha $\mathrm{hr}^{-1}$ (Mutert and Fairhurst, 1999). Though, fossil and historical evidence suggested that Africa, probably, West Africa is the original home of the oil palm (Gray, 1969), this crop is fast being identified with Malaysia (Kajisa et al., 1997), due to better environmental conditions for oil palm in that part of the world. Although the crop takes a long time to manifest responses to fertilizers as well as other agronomic treatments, it shows good responses at the early growth stage (Hartley, 1988).

There is a need to explore soil fertility opportunities derivable from nutrient recycling through incorporation of plant residues to the soil and use less of mineral fertilizers. It has been discovered that $\mathrm{N}$ sources of fertilizers (urea and ammonium sulphate) mostly used in the tropics result to an increase in yield for some years but in the long run could lead to decreasing base saturation, acidification, thus reducing the soil fertility (Phicot et al, 1981). One of the major degradable wastes of oil palm plantations is oil palm empty fruit bunch (EFB). Oil palm EFB is the remnant of the harvested ripe female inflorescence with the fruits removed for oil extraction. EFB is a suitable raw material for recycling because it is produced in large quantities in localized areas. In the past, it was often used as fuel to generate steam at the mills, but now, open burning is becoming more prohibited globally to prevent air pollution (Ma et al. 1993). The ash, with a potassium content of about 30\%, (Zaharah and Lim, 2000) was used as fertilizer. The EFB is now used mainly as mulch (Hamdan et al. 1998). Placed around young palms, EFB helps to control weeds, prevent erosion and maintain soil moisture. However, due to the current labour shortage, the transportation and distribution of EFB in the field is getting more expensive. There is a growing interest in composting $\mathrm{EFB}$, in order to add to its value, and also to reduce the volume; making application easier (Yusri et al. 1995, Thambirajah et al. 1995; Danmanhuri 1998). Aisueni and Omoti (1999) reported that oil palm industry is one of the best sources of agricultural wastes that can be used as organic fertilizers. According to the authors, the palm industry in Nigeria produces 40 million metric tonnes FFB (fresh fruit bunch) annually, of which about 16 million tonnes of empty bunch refuse can be composted into organic fertilizer. Though oil palm EFB is very fibrous and not easily compostable, cow dung could be used to improve its compost ability. This research effort was directed at studying the rates of release of nutrients by different EFB compost treatments as affected by time, their influence on soil $\mathrm{pH}$ and nutrient uptake by oil palm seedlings.

\section{Methodology}

\section{Experimental Site}

Incubation and planting were carried out in the Department of Agronomy, University of Ibadan, Ibadan, Nigeria (located approximately between latitudes $3^{\circ} 48^{\prime}$ and $4^{\circ} 0^{\prime} \mathrm{E}$ and longitude $7^{\circ} 25^{\prime}$ and $7^{0} 30^{\prime}$ E) between February 2001 and November 2003. The experimental soil can be regarded as being poor in fertility (especially for oil palm production) due to its low content of macro nutrients (Table 2). The soil was rain washed and originally meant to produce a "sand culture" that can easily allow the manifestation of plants' responses to applied fertilizer treatments. The soil was passed through $2 \mathrm{~mm}$ sieve. The total $\mathrm{N}$ content $\left(0.1 \mathrm{~g} \mathrm{~kg}^{-1}\right)$ was very low (Sobulo et al, 1975, Fed. Min. of Agric. and Nat. Res., 1989). The Mechlich's III available soil P content (14 mg kg-1) is on a medium level for soils of South-western Nigeria (Agboola and Corey, 1972; Agboola and Obigbesan, 1974). Also, the extractable K (Mechlich III) was low (Fed. Min. of Agric. and Nat. 
Res., 1989). The neutral $\mathrm{pH}$ of the soil was within a safe range for most crops (Helyar et al., 1990), though oil palm is tolerant to low pH soils (Hartley, 1988; von Uexkull, 1992).

\section{Compost Treatments}

The following were used as fertilizer treatments;
1. Control (no application)
2. $100 \%$ unsoaked oil palm empty fruit bunch (UEFB)
3. $80 \%$ UEFB $+20 \%$ cow dung
4. $60 \%$ UEFB $+40 \%$ cow dung
5. $100 \%$ soaked oil palm empty fruit bunch (SEFB)
6. $80 \%$ SEFB $+20 \%$ cow dung
7. $60 \%$ SEFB $+40 \%$ cow dung
8. Cow dung
9. Mineral fertilizer (N:P:K:Mg - 12:12:17:2)

EFB and cow dung ratios were based on dry constant weight in oven at $70^{\circ} \mathrm{c}$. The composts were milled to pass through $2 \mathrm{~mm}$ sieve before applying to the soils of the treatments.

\section{Laboratory Incubation Study}

The study was conducted as a laboratory-based work using the method described by Wieder and Lang (1982). The compost treatments listed above were applied to soil at the rate of $20 \mathrm{tha}^{-1}$ (i.e. $0.8 \mathrm{~g}$ compost per plastic cup with $40 \mathrm{~g}$ soil each) and incubated for a period of 10 months to mimic the behaviour of the treatments in experimental soils. The cups with soils were placed in an incubation chamber, covered and kept at field capacity throughout the experimental period of 10 months. Average temperature during incubation was $29{ }^{\circ} \mathrm{C}$. Treatments were terminated at 3,6 and 10 months interval for analysis of the released essential nutrients and the soils $\mathrm{pH}$.

\section{Oil palm Nursery}

'Tenera' oil palm germinated seeds from Nigerian Institute for Oil Palm Research (NIFOR) were planted in black polythene bags. The number of treatments was 9, replicated three times, hence a total of 27 samples, arranged in a randomised complete block design. The volume of the soil was 5 $\mathrm{kg}$ per bag and the plants were exposed to prevailing environmental factors like rain and erosion. All the compost treatments and urea (mineral fertilizer) treatments were applied at the on-set of the pre-nursery stage $(0-3$ months old $)$ of the seedlings. Only mineral N-P-K-Mg: 12-12-17-2 compound fertilizer treatment at a rate of 14g per plant (NIFOR, 1972; NIFOR 1973; Onwubuya, 1982) was applied twice (2nd and 8th months) in the observed nursery period. Plants were watered regularly to field capacity and manual weeding was done when due. Physical-chemical analyses

The physical and chemical analysis of the experimental soils was carried out before the treatments were added to the soils to determine the nutrient status of the soils. The soil was air-dried and sieved using a $2 \mathrm{~mm}$ sieve. Particle size distribution was determined by hydrometer method (Bouyoucus, 1962). Soils $\mathrm{pH}$ was determined using 1: 1.25 soil: $\mathrm{CaCl}_{2}$ solution with $\mathrm{pH}$ meter. Plants were digested using the dry ash method. Nitrogen was determined by Dumas method (Simonne et al, 1995). Mehlich's III method (Mehlich, 1984) was used to extract phosphorus, potassium, calcium, magnesium, copper, zinc, iron and manganese. The $\mathrm{P}$ concentration was determined using a spectrophotometer with vanadium-molybdate solution as the indicator. Potassium and calcium were measured with a Flame-Photometer, magnesium, copper; zinc, iron and manganese were measured with an Atomic-Absorption Spectrophotometer. Statistical analysis

Correlations of nutrient concentrations released with time and corresponding $\mathrm{pH}$ values were carried out with the aid of Microsoft Excel 2000. Level of significance of the correlation values was done with the aid of correlation table and means of nutrient uptake were separated with Duncan Multiple Range Test (DMRT) and standard error at 5\% probability level. 
Table 1: Nutrients Composition of Compost Treatments on Dry Matter Basis

\begin{tabular}{clllllll}
\hline Nutrients & \multicolumn{7}{c}{ Compost materials } \\
\cline { 2 - 8 } & $\begin{array}{l}100 \% \\
\text { UEFB }\end{array}$ & $\begin{array}{l}80 \% \text { UEFB } \\
+20 \% \text { cow } \\
\text { dung }\end{array}$ & $\begin{array}{l}60 \% \text { UEFB } \\
+40 \% \text { cow } \\
\text { dung }\end{array}$ & $\begin{array}{l}100 \% \\
\text { SEFB }\end{array}$ & $\begin{array}{l}80 \% \text { SEFB } \\
+20 \% \text { cow } \\
\text { dung }\end{array}$ & $\begin{array}{l}60 \% \text { SEFB } \\
+40 \% \text { cow } \\
\text { dung }\end{array}$ & $\begin{array}{l}\text { Cow } \\
\text { dung }\end{array}$ \\
\hline $\mathrm{g} \mathrm{kg}^{-1}$ & & & & & & & \\
$\mathrm{~N}$ & 8.70 & 11.30 & 11.90 & 11.40 & 12.80 & 15.00 & 26.80 \\
$\mathrm{C}$ & 451.50 & 420.00 & 444.50 & 433.00 & 457.00 & 437.50 & 303.00 \\
$\mathrm{C}: \mathrm{N}$ & 519.00 & 371.70 & 378.90 & 381.90 & 360.60 & 304.50 & 113.30 \\
$\mathrm{P}$ & 0.90 & 1.00 & 1.10 & 0.60 & 0.60 & 1.30 & 3.20 \\
$\mathrm{~K}$ & 10.80 & 11.70 & 11.90 & 6.60 & 6.30 & 11.00 & 37.70 \\
$\mathrm{Ca}$ & 3.20 & 4.30 & 4.70 & 4.00 & 2.70 & 4.40 & 15.60 \\
$\mathrm{Mg}$ & 3.40 & 3.50 & 4.00 & 3.40 & 2.30 & 3.70 & 9.40 \\
$\mathrm{~S}$ & 1.70 & 2.00 & 2.10 & 2.00 & 1.20 & 2.10 & 4.80 \\
$\mathrm{mg} \mathrm{kg}$ & & & & & & & \\
$\mathrm{Zn}$ & 84 & 64 & 99 & 71 & 72 & 85 & 135 \\
$\mathrm{Cu}$ & 21 & 18 & 19 & 14 & 13 & 18 & 24 \\
$\mathrm{Mn}$ & 152 & 132 & 144 & 157 & 105 & 153 & 365 \\
$\mathrm{Fe}$ & 618 & 471 & 650 & 668 & 551 & 644 & 2847 \\
\hline
\end{tabular}

UEFB is unsoaked empty fruit bunch and SEFB is the soaked empty fruit bunch

Table 2: Physicochemical Properties of Experimental Soil

$\begin{array}{ll}\text { Parameters } & \text { Value } \\ \mathrm{pH}\left(\mathrm{CaCl}_{2}\right) & 7.00 \\ \text { Org. } \mathrm{C}\left(\mathrm{g} \mathrm{kg}^{-1}\right) & 4.80 \\ \text { Total }\left(\mathrm{g} \mathrm{kg}^{-1}\right) & 0.20 \\ \mathrm{P}\left(\mathrm{mg} \mathrm{kg}^{-1}\right) & 14 \\ \text { Exchangeable bases }\left(\mathbf{c ~} \mathbf{~ m o l ~} \mathbf{~ k g}^{-1}\right) & \\ \mathrm{K} & 0.1 \\ \mathrm{Mg} & 0.2 \\ \mathrm{Ca} & 1.1 \\ \mathrm{CEC} & 1.6 \\ \left.\text { Extractable micronutrients } \mathbf{( m g ~ k g}^{-1}\right) & \\ \mathrm{Mn} & 41 \\ \mathrm{Fe} & 55 \\ \mathrm{Cu} & 1 \\ \text { Zn } & 8 \\ \text { Mechanical composition }\left(\mathbf{g ~ k g}^{-1}\right) & \\ \text { Sand } & 930 \\ \text { Silt } & 50 \\ \text { Clay } & 20 \\ \text { Textural Class } & \text { Sand }\end{array}$

\section{Results and Discussion}

The summary of results of the quantities of nutrients released due to the compost treatments used is shown in Table 3. During the 10 months incubation period, relationship between the amount of $\mathrm{N}$ released and incubation period was least $(r=0.07)$ with the control and best $(r=0.90)$ with unsoaked EFB/ cow dung combination at 60: 40 ratio (Table 4). The amount of phosphorus released with time was least in the $100 \%$ unsoaked empty fruit bunch treatment $(r=0.12)$ and highest $(r=1.00)$ with the unsoaked EFB: cow dung $-60: 40 \%$. Quantity of potassium released with time was lowest $(\mathrm{r}=0.17)$ with the $100 \%$ soaked oil palm empty fruit bunch and highest $(\mathrm{r}=$ 1.00) with the soaked EFB/ cow dung treatment at the ratio of 60: 40 as well as the cow dung treatment. The quantity of calcium released with time was least $(r=0.04)$ with the $100 \%$ oil palm empty fruit bunch and highest $(r=1.00)$ with the unsoaked EFB/ cow dung at the ratio of 80: 20 treatments. The relationship between amount of magnesium released with the period of incubation 
was least $(r=0.12)$ with $100 \%$ soaked empty fruit bunch and highest $(r=1.00)$ with both soaked EFB/ cow dung (ratio 60: 40) and the cow dung treatments. The relationship of quantities of manganese released with period of incubation was least $(r=0.04)$ in $100 \%$ soaked empty fruit bunch and highest $(r=1.00)$ in soaked EFB: cow dung (80:20) treated soils respectively. The lowest relationship $(r=0.19)$ of Zinc released with time was recorded in the $100 \%$ unsoaked empty fruit bunch and highest $(\mathrm{r}=1.00)$ in cow dung treated soils. The quantity of iron released with time was least $(r=0.22)$ in the cow dung and highest $(r=0.99)$ in unsoaked EFB: cow dung (80: 20) and both soaked and unsoaked EFB: cow dung (60: 40) treatments respectively.

The relationship between $\mathrm{N}$ released and soil $\mathrm{pH}$ changes within the time of incubation was least $(r=0.52)$ in control (no additive) and highest $(r=1.00)$ in unsoaked EFB: cow dung (80: 20) soils respectively. In the case of $P$, the least relationship $(r=0.26)$ resulted from the unsoaked EFB: cow dung (60: 40) soil and highest $(\mathrm{r}=1.00)$ in the $100 \%$ soaked EFB treated soils. The relationship between $\mathrm{K}$ released and soil $\mathrm{pH}$ changes within the time of incubation was least $(\mathrm{r}=$ 0.17) in unsoaked EFB: cow dung (80: 20) and highest $(r=0.96)$ in soaked EFB: cow dung (60: 40) soils. The relationship was lowest $(\mathrm{r}=-0.56)$ in $\mathrm{Ca}$ with cow dung treated soil and highest $(1.00)$ in soaked EFB: cow dung (60: 40) treated soil. This relationship with respect to $\mathrm{Mg}$ was lowest $(\mathrm{r}=$ $0.02)$ in the control soil and highest $(r=0.94)$ in soaked EFB: cow dung (60: 40) soil. The relationship between $\mathrm{Mn}$ released and soil $\mathrm{pH}$ changes within the time of incubation was lowest $(\mathrm{r}=$ -0.06) in unsoaked EFB: cow dung (60: 40) and highest $(r=0.99)$ in both $100 \%$ unsoaked $\mathrm{EFB}$ and cow dung soils respectively. The relationship was lowest $(\mathrm{r}=-0.11)$ in $\mathrm{Zn}$ with control and highest $(\mathrm{r}=0.19)$ in $100 \%$ soaked EFB soils respectively. In term of Fe released with time and soil $\mathrm{pH}$ changes, the relationship was least $(\mathrm{r}=0.36)$ in soaked EFB: cow dung (80: 20) and highest $(\mathrm{r}=$ $0.98)$ in the both soaked and unsoaked EFB: cow dung (60: 40) treated soils respectively. These results are shown on Table 5.

Though was no significant $(\mathrm{p}<0.05)$ difference in the total dry weights of plants in all the oil palm empty fruit bunch treatments (Figure 1), but the unsoaked EFB: cow dung - 60: 40\% compost treatment performed significantly better than the control treatment. Nutrients uptake in soil by the oil palm seedlings was not regular in pattern (Table 6). The highest mean uptake of Nitrogen was in the mineral fertilizer treatment $\left(0.28 \mathrm{~g}_{\text {plant }}{ }^{-1}\right)$. Least $\mathrm{N}$ uptake was with soaked EFB: cow dung (80: 20) cow compost treatment. There was no significant difference in the $\mathrm{P}$ uptake by the plants in all the treatments, but ranged between 0.01 and $0.03 \mathrm{~g} \mathrm{plant}^{-1}$. The mean uptake of potassium by the plants was least $\left(0.16 \mathrm{~g} \mathrm{plant}^{-1}\right)$ in the control treatment and highest $\left(0.31 \mathrm{~g} \mathrm{plant}^{-1}\right)$ in unsoaked EFB: cow dung - 60: $40 \%$ compost treatment. Mean uptake of calcium $\left(0.06 \mathrm{~g} \mathrm{plant}^{-1}\right)$ was lowest in soaked EFB: cow dung (80: 20) compost treatment and highest $\left(0.14 \mathrm{~g} \mathrm{plant}^{-1}\right)$ in unsoaked EFB: cow dung (60: 40) compost treatment. In magnesium, mean uptake was least $\left(0.02 \mathrm{~g} \mathrm{plant}^{-1}\right)$ in soaked EFB: cow dung (80: 20) compost treatment and highest $\left(0.07 \mathrm{~g}\right.$ plant $\left.^{-1}\right)$ in unsoaked EFB: cow dung (60: 40) compost treatment. The least $\left(0.01 \mathrm{~g} \mathrm{plant}^{-1}\right)$ mean uptake of sulphur was recorded in soaked EFB: cow dung - 80: $20 \%$ and 60: 40\% compost treatments and highest in the mineral, 100\% unsoaked and unsoaked EFB: cow dung (60: 40) treatments. Marginal leaf necrosis, typical of manganese toxicity (Hochmuth et al., 2004) was observed in the plants treated with cow dung. These plants died shortly after 3 months in the nursery. 
Table 3: Release of Nutrient Element from Soils Treated to Different Treatments of Oil Palm Empty Fruit Bunch Composts in Soil during Laboratory Incubation

\begin{tabular}{|c|c|c|c|c|c|c|c|}
\hline Treatments & $\begin{array}{l}\text { Months of } \\
\text { incubation }\end{array}$ & $\begin{array}{l}\mathbf{p H} \\
\mathrm{CaCl}_{2}\end{array}$ & $\begin{array}{l}\text { TN } \\
\mathrm{g} \mathrm{kg}^{-1}\end{array}$ & $\begin{array}{l}\text { Av. } \mathbf{P} \\
\mathrm{mg} \mathrm{kg}^{-1}\end{array}$ & $\frac{\mathrm{K} \text { Ca MgECEC }}{\frac{\mathrm{C} \mathrm{mol} \mathrm{kg}{ }^{-1} \text { soil }}{}}$ & $\begin{array}{l}\mathrm{MnZn} \mathrm{Cu} \\
\mathrm{mg} \mathrm{kg}^{-1}\end{array}$ & \\
\hline Initial soil & 0 & 7.0 & 0.2 & 14 & 0.11 .10 .216 & 4181 & 55 \\
\hline Control (no additive) & 3 & 7.3 & 0.1 & 34 & 0.11 .60 .224 & 27101 & 47 \\
\hline $100 \%$ UEFB & 3 & 7.0 & 0.3 & 29 & 0.51 .80 .626 & 73101 & 116 \\
\hline $80 \%$ UEFB $+20 \%$ cow dung & & 7.0 & 0.4 & 45 & 0.82 .20 .943 & 83121 & 151 \\
\hline $60 \%$ UEFB $+40 \%$ cow dung & & 6.8 & 0.3 & 42 & 0.91 .80 .740 & 42101 & 56 \\
\hline $100 \%$ SEFB & 3 & 7.1 & 0.3 & 33 & 0.52 .30 .840 & 74151 & 121 \\
\hline $80 \%$ SEFB $+20 \%$ cow dung & & 6.8 & 0.3 & 36 & 0.52 .00 .843 & 43151 & 50 \\
\hline $60 \%$ SEFB $+40 \%$ cow dung & & 7.0 & 0.4 & 57 & 0.82 .40 .936 & 71121 & 99 \\
\hline Cow dung & 3 & 7.1 & 0.4 & 130 & 1.62 .30 .873 & 2971 & 43 \\
\hline Control (no additive) & 6 & 7.1 & 0.1 & 27 & 0.11 .70 .332 & 40311 & 40 \\
\hline $100 \%$ UEFB & 6 & 6.7 & 0.3 & 41 & 0.82 .30 .843 & 41151 & 55 \\
\hline $80 \%$ UEFB $+20 \%$ cow dung & & 6.7 & 0.3 & 42 & 0.91 .90 .947 & 64131 & 113 \\
\hline $60 \%$ UEFB $+40 \%$ cow dung & & 6.6 & 0.3 & 48 & 1.01 .90 .842 & 34101 & 48 \\
\hline $100 \%$ SEFB & 6 & 6.8 & 0.4 & 28 & 0.51 .90 .638 & 49101 & 78 \\
\hline $80 \%$ SEFB $+20 \%$ cow dung & & 6.8 & 0.5 & 29 & 0.41 .90 .635 & 6491 & 143 \\
\hline $60 \%$ SEFB $+40 \%$ cow dung & & 6.7 & 0.3 & 55 & 0.72 .20 .844 & 48121 & 76 \\
\hline Cow dung & 6 & 7.0 & 0.3 & 155 & 1.83 .01 .065 & 63101 & 63 \\
\hline Control (no additive) & 10 & 7.2 & 0.2 & 28 & 0.11 .60 .324 & 2881 & 42 \\
\hline $100 \%$ UEFB & 10 & 6.8 & 0.2 & 28 & 0.61 .90 .734 & 4391 & 43 \\
\hline $80 \%$ UEFB $+20 \%$ cow dung & 10 & 6.7 & 0.3 & 30 & 0.71 .60 .739 & 3081 & 30 \\
\hline $60 \%$ UEFB $+40 \%$ cow dung & & 6.9 & 0.5 & 57 & 0.81 .70 .743 & 2871 & 28 \\
\hline $100 \%$ SEFB & 10 & 6.8 & 0.3 & 29 & 0.52 .30 .836 & 73111 & 94 \\
\hline $80 \%$ SEFB $+20 \%$ cow dung & 10 & 6.7 & 0.4 & 50 & 0.52 .30 .840 & 35161 & 50 \\
\hline $60 \%$ SEFB $+40 \%$ cow dung & 10 & 6.6 & 0.3 & 42 & 0.62 .00 .635 & 57111 & 57 \\
\hline Cow dung & 10 & 7.1 & 0.4 & 205 & 2.03 .61 .361 & 49151 & 49 \\
\hline
\end{tabular}

Table 4: Coefficients of Correlation Relating Nutrient Concentrations with Time of Nutrient Release by Different Treatments of Oil Palm Empty Fruit Bunch (EFB) Composts in Soils after 10 Months of Incubation

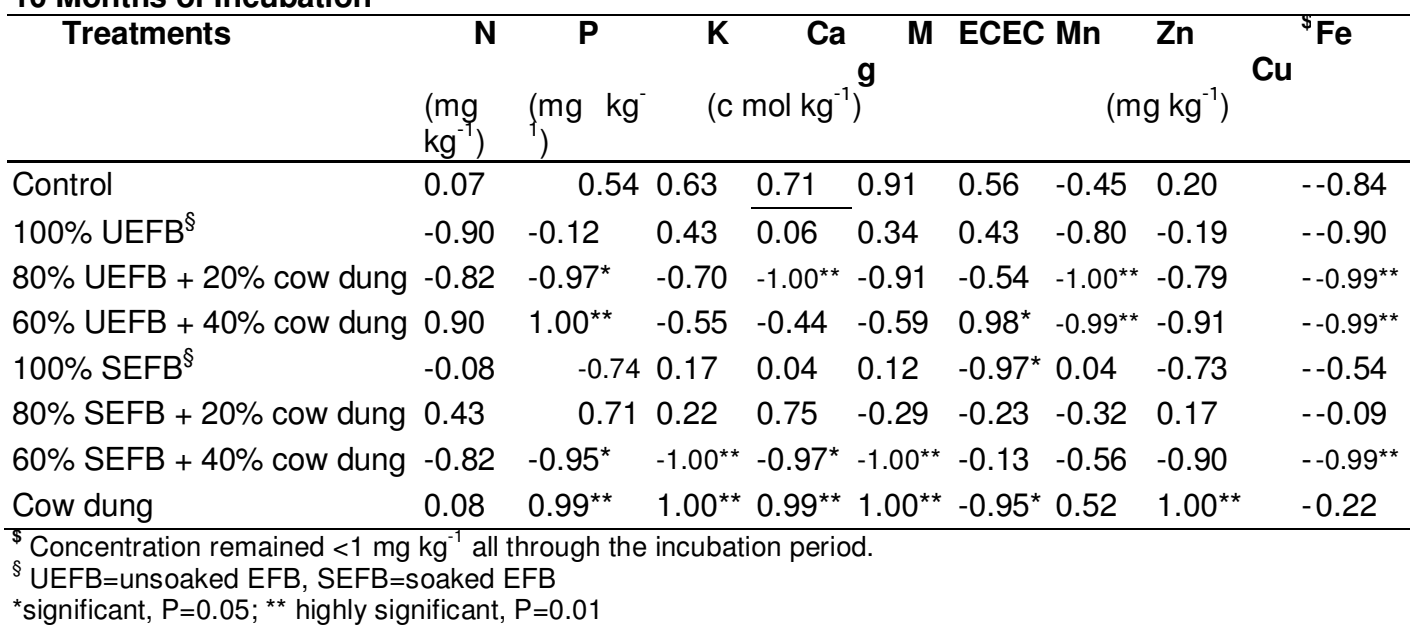


Table 5: Coefficients of Correlation Relating Nutrient Concentrations with pH of different Treatments of Oil Palm Empty Fruit Bunch (EFB) Composts in Soils after 10 Months of Incubation

\begin{tabular}{|c|c|c|c|c|c|c|c|c|c|c|}
\hline Treatments & $\begin{array}{c}\mathbf{N} \\
\left(\mathrm{g} \mathrm{kg}^{-1}\right)\end{array}$ & $\begin{array}{c}\mathbf{P} \\
\left(\mathrm{mg} \mathrm{kg}^{-1}\right)\end{array}$ & & $\begin{array}{l}\mathrm{Ca} \\
\mathrm{mol} \mathrm{kg}\end{array}$ & $\begin{array}{l}\mathbf{M g} \\
\left.{ }^{7}\right)\end{array}$ & ECEC & Mn & $\begin{array}{c}\mathbf{Z n} \\
\left.\mathrm{g} \mathrm{kg}^{-1}\right)\end{array}$ & $\mathrm{Cu}$ & $\mathrm{Fe}$ \\
\hline$\overline{\text { Control }}$ & -0.52 & $0.96^{*}$ & 0.82 & 0.76 & 0.02 & 0.43 & -0.90 & -0.11 & -0.54 & 0.48 \\
\hline $100 \%$ UEFB $^{\S}$ & 0.31 & -0.63 & $-0.95^{*}$ & -0.77 & -0.92 & $-0.95^{*}$ & $0.99^{* *}$ & -0.58 & -0.47 & 0.94 \\
\hline $80 \%$ UEFB $+20 \%$ cow dung & $1.00^{\star \star}$ & 0.65 & 0.17 & 0.85 & 0.52 & -0.04 & 0.78 & 0.30 & 0.86 & 0.74 \\
\hline $60 \%$ UEFB $+40 \%$ cow dung & 0.62 & 0.26 & -0.94 & $-0.97^{*}$ & -0.92 & 0.03 & -0.06 & 0.61 & -0.76 & -0.37 \\
\hline $100 \%$ SEFB $^{\S}$ & -0.55 & $1.00^{* *}$ & 0.47 & 0.58 & 0.51 & 0.91 & 0.58 & $1.00^{* *}$ & 0.85 & 0.94 \\
\hline $80 \%$ SEFB $+20 \%$ cow du & -0.16 & -0.88 & -0.48 & -0.91 & 0.01 & -0.06 & 0.57 & -0.44 & -0.79 & 0.36 \\
\hline $60 \%$ SEFB $+40 \%$ cow dung & $0.96^{*}$ & 0.79 & $0.96^{*}$ & $1.00^{* *}$ & 0.94 & -0.20 & 0.80 & 0.90 & 0.29 & $0.98^{* *}$ \\
\hline Cow dung & 0.87 & -0.33 & -0.43 & -0.56 & -0.34 & 0.68 & $-0.99^{* *}$ & 0.35 & -0.77 & $-0.98^{*}$ \\
\hline
\end{tabular}

§ UEFB=unsoaked EFB, SEFB=soaked EFB

*significant, $P=0.05 ;{ }^{*}$ highly significant, $P=0.01$

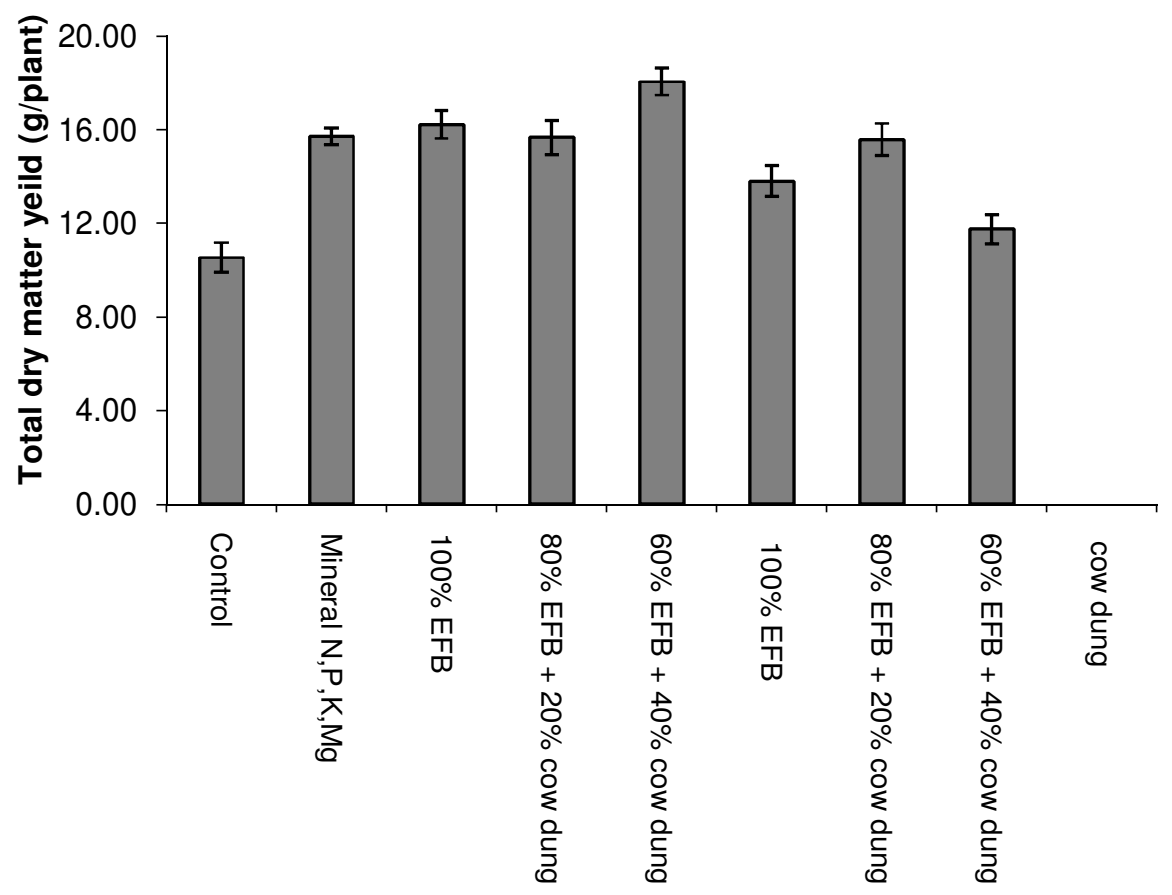

Fertilizer Treatments

Figure 1: Effect of Oil Palm Empty Fruit Bunch (EFB) Compost on Oil Palm Dry Matter Yield at 10 Months in Nursery

Note: Bars indicate standard error $(p<0.05)$ 
Table 6: Effect of Oil Palm Empty Fruit Bunch (EFB) Treatments on Nutrient Uptake of Oil Palm after 10 Months of Growth in Nursery

\begin{tabular}{|c|c|c|c|c|c|c|c|c|c|}
\hline \multirow{2}{*}{ Nutrien } & \multicolumn{9}{|c|}{ Compost treatments } \\
\hline & Control & $\begin{array}{l}\text { Mineral } \\
\text { fertilizer } \\
\text { (NPKMg) }\end{array}$ & $\begin{array}{l}100 \% \\
\text { UEFB }\end{array}$ & $\begin{array}{l}80 \% \\
\text { UEFB + } \\
20 \% \text { cow } \\
\text { dung }\end{array}$ & $\begin{array}{l}60 \% \\
\text { UEFB + } \\
40 \% \text { cow } \\
\text { dung }\end{array}$ & $\begin{array}{l}100 \% \\
\text { SEFB }\end{array}$ & $\begin{array}{l}80 \% \\
\text { SEFB + } \\
20 \% \text { cow } \\
\text { dung }\end{array}$ & $\begin{array}{l}60 \% \\
\text { SEFB + } \\
40 \% \text { cow } \\
\text { dung }\end{array}$ & $\begin{array}{l}\text { Cow } \\
\text { dung }\end{array}$ \\
\hline \multicolumn{10}{|l|}{$\mathrm{g} \mathrm{plant}^{-1}$} \\
\hline $\mathrm{N}$ & $0.13 \mathrm{~ns}$ & $0.28 \mathrm{~ns}$ & $0.19 \mathrm{~ns}$ & $0.18 \mathrm{~ns}$ & $0.22 \mathrm{~ns}$ & $0.17 \mathrm{~ns}$ & $0.12 \mathrm{~ns}$ & $0.15 \mathrm{~ns}$ & - \\
\hline$P$ & $0.02 b c$ & 0.0 & $0.02 a b$ & $0.03 a$ & $0.03 a$ & $0 .($ & $0.01 \mathrm{a}$ & $0.02 \mathrm{ab}$ & - \\
\hline K & $0.16 a$ & $0.24 a$ & $0.29 a$ & $0.22 a$ & $0.31 a$ & $0.22 a$ & $0.17 \mathrm{a}$ & $0.21 a$ & - \\
\hline $\mathrm{Ca}$ & $0.07 \mathrm{~b}$ & $0.08 \mathrm{ab}$ & $0.10 \mathrm{ab}$ & $0.10 \mathrm{ab}$ & $0.14 \mathrm{a}$ & $0.11 a b$ & $0.06 a b$ & $0.08 a b$ & - \\
\hline $\mathrm{Mg}$ & $0.03 \mathrm{bc}$ & $0.04 a b c$ & $0.05 a b c$ & $0.06 \mathrm{ab}$ & $0.07 a$ & $0.05 a b c$ & $0.02 a b c$ & $0.05 a b$ & - \\
\hline $\begin{array}{l}\text { S } \\
\text { g plant }\end{array}$ & $0.02 a b$ & $0.03 a$ & 0.0 & $0.02 \mathrm{ab}$ & $0.03 a$ & 0.0 & $0.01 \mathrm{ab}$ & $0.01 \mathrm{~b}$ & - \\
\hline $\mathrm{Zn}$ & $0.33 \mathrm{bcd}$ & & & bc & $0.53 a b c$ & $0.37 k$ & $0.47 \mathrm{bc}$ & $0.37 \mathrm{bc}$ & - \\
\hline & $0.03 b c$ & $0 .($ & $\mathrm{abb}$ & $0.05 a b$ & $0.05 a b$ & $0.04 b$ & $0.05 a b$ & $0.04 b c$ & - \\
\hline $\mathrm{Mn}$ & $3.31 b c$ & $18.92 \mathrm{a}$ & $4.07 b$ & $3.38 b$ & $4.18 b$ & $2.90 \mathrm{bc}$ & $3.10 b c$ & $2.48 b c$ & - \\
\hline $\mathrm{Fe}$ & $16.67 \mathrm{cde}$ & $40.00 a$ & $36.67 \mathrm{ab}$ & $26.67 \mathrm{abcd}$ & 33.33abc & 23.33adcd & 33.33abc & $20.00 \mathrm{bcd}$ & - \\
\hline
\end{tabular}

Means with same letters in the rows are not significantly different $(\mathrm{p}<0.05)$ using DMRT

ns $=$ means not significant at $\mathrm{p}<0.05$

${ }^{c}$ Plants died shortly after 3 months in the nursery

\section{Nutrient Release Pattern of Different Treatments of Oil Palm Empty Fruit Bunch in Soil}

Result of the correlation of amount of nutrients released (from the soil treated to the various composts) with time and $\mathrm{pH}$ are shown in Tables 4 and 5 respectively. The high significant correlation $(\mathrm{p}<0.01)$ in respect of available $\mathrm{P}$ released and time recorded in unsoaked EFB: cow dung 60:40 and cow dung treated soils indicates the constant rate of $\mathrm{P}$ mineralization by these treatments over the others. Generally, $\mathrm{P}$ fixation is influenced by $\mathrm{pH}$ value but since these two treatments had no significant correlation between $\mathrm{P}$ released and $\mathrm{pH}$ value, it can be concluded that they were better $P$ sources than other than treatments used in this experiment.

The highly significant $(\mathrm{p}<0.01)$ negative correlation of extractable potassium released with time by the soaked EFB: cow dung 60:40 implies that $\mathrm{K}$ produced by this treatments was fixed by either clay or organic contents of the soil with time (Ogunremi, 1977; Adeoye, 1986) or there was a very high release in the early part and then a decrease with time. Also, this particular treatment of EFB compost revealed a significant positive correlation between $\mathrm{K}$ and $\mathrm{pH}(\mathrm{p}<0.01)$. This means $\mathrm{K}$ released in this compost treated soil was $\mathrm{pH}$ dependent. Though Mengel and Kirkby (2001) reported that higher $\mathrm{pH}$ leads to increasing availability of basic cations like $\mathrm{K}, \mathrm{Ca}$ and $\mathrm{Mg}$, but the reality in most oil palm soils is reduction in $\mathrm{pH}$ with time. This means that soaked EFB: cow dung 60:40 having lower $\mathrm{K}$ content (Table 1) might not be a good source of $\mathrm{K}$ in this soil. Release pattern of extractable calcium and magnesium by the applied treatments was similar to that observed in $\mathrm{K}$.

The high negative correlation $(\mathrm{p}<0.001)$ of manganese and iron released with time by unsoaked EFB: cow dung 80:20\% and 60:40 composts is an indication that their Mn and Fe were probably chelated with time by the soil organic matter. This could be a good characteristic of these composts considering the susceptibility of oil palm soils under low $\mathrm{pH}$ (below 5.0) condition to Mn toxicity (Hartley, 1988; von Uexkull, 1992). The concentration of $\mathrm{Cu}$ in the soil did not vary within the 10month period of this experiment (as shown in Table 2). This indicated that applied treatments did not improve extractable $\mathrm{Cu}$ concentration in the soil, which might be a result of low $\mathrm{Cu}$ concentration in the applied composts, as shown in Table 4. The marginal change in $\mathrm{Cu}$ concentration in leaves of oil palm nursery at 10 months resulting from the application of these treatments as shown in Table 6 is in support of the report by von Uexkull (1992) that Cu deficiency is common in highly leached sandy soils in high rainfall areas.

\section{Nutrient uptake by oil palm in the nursery}

Dry matter accumulation was better in the unsoaked EFB: cow dung 60:40 compost treatment than other treatments, Also, nutrient uptake of plants under this treatment was comparable to those under 
mineral fertilizer treatment (except in manganese). Again, this could be as a result of better nutrient release pattern of this EFB treatment among other EFB treatments under the prevailing environmental condition during the planting period. This is a good indication that the unsoaked EFB: cow dung 60: 40 compost performed better than other treatments used in this experiment.

\section{Conclusion}

Plant essential nutrients' release pattern of $40 \%$ inclusion of cow dung in unsoaked EFB compost seems to be better than those of the other EFB composts used in this investigation. This organic treatment could then be suggested as a cheaper source to fertilize oil palm soils, especially when the plant is in the nursery. Since oil palm EFB is readily available in oil palm plantations, this compost will be a good alternative to the conventional mineral fertilizer commonly used to grow oil palms. Thus, the use of $40 \%$ inclusion of cow dung in unsoaked EFB compost will go a long way to avoid the problem of unavailability and high costs associated with mineral fertilizers in the production of the crop.

\section{Acknowledgement}

The author gratefully acknowledges the assistance of Dr. Thomas Gaiser, Dr. Carsten Reinbrecht and Dr. E. A. Akinrinde and the supervision of Prof. G. O. Adeoye. The author also acknowledges the Nigerian Institute for Oil Palm Research (NIFOR) for support with oil palm seeds and laboratory analyses and DAAD for funding the study.

\section{References}

AdeOluwa, O. O. and Adeoye, G. O., 2008. Potential of Oil Palm Empty Fruit Bunch (EFB) as Fertilizer in oil Palm (Elaeis guineensis L Jacq.) Nurseries. Proceeding of the Second Conference of the International Society of Organic Agriculture Research (ISOFAR) held at the 16th IFOAM Organic World Congress, Modena, Italy, June 16-20, 2008. Daniel Neuhoff, Niels Halberg, Thomas Alföldi, William Lockeretz, Andreas Thommen, Ilse. A. Rasmussen, John Hermansen, Mette Vaarst, Lorna Lueck, Fabio Caporali, Henning Hogh Jensen, Paola Migliorini, Helga Willer (Eds.) pp 86 - 89.

Adeoye, G. O., 1986. Comparative studies of Ammonium bifloride chelate extractants and some conventional extractants for sediments soils of South-western Nigeria. PhD Thesis, Department of Agronomy, University of Ibadan, Ibadan, Nigeria. Unpublished.

Agboola, A. A. and Corey, R. B., 1972. Soil test calibration for maize in soils derived from metamorphic and igneous rocks of Western Nig. J. West African Sc. Ass. 17: 93-100

Agboola, A. A. and Obigbesan, G. O., 1974. The response of some improved food crop varieties to fertilizers in the forest zone of Nigeria. Report on the FAO/NORAD and Federal Department of Agriculture Seminar on Fertilizer Use Development in Nigeria, Ibadan, Nigeria, 1-9 April 1974, FAO, Rome (Italy). Land and Water Development Div., 1976. FAO-AGL--TF-AFR-57(NOR). p. 63-77.

Aisueni, N. O. and OMOTI, U. (1999). The making of compost from empty oil palm refuse. Books of Abstracts; Soil Science Society of Nigeria conference, Benin. 21-25 Nov. 1999, pp 48-49.

Bouyoucus, C. J., 1962. Hydrometer method: Improved for making particle size analysis of soils. Agronomy Journal. 54: 465-467

Danmanhuri, M.A., 1998. Hands-on experience in the production of empty fruit bunch (EFB) compost. Paper presented at the CETDEM Malaysian Organic Farming Seminar. Petaling, Jaya, Selangor, Malaysia. Page 50 - 61. Downloaded on 24th of April, 2004

Federal Min. of Agric., Water Res. and Nat. Devpt. Lagos, 1989. Fertilizer use and Mgt. Practices for crops in Nigeria. Pp: 163

Gray, B.S., 1969. The potential of the oil palm. Malaysia. Journal of Tropical Geography. 17: 127132 
Hamdan, A. B., Ahmad, T. M. and Mohd, T. D., 1998. Empty fruit bunch mulching and nitrogen fertilizer amendment: The resultant effect on oil palm performance and soil properties. PO RIM Bulletin No. 37, 1-14.

Hartley, C. W., 1988. The Oil Palm, Third Edition, Longmans Scientific and Technical London. pp. 761

Helyar, K. R., Cregan, P. D. and Godyn, D. L., 1970. Soil acidity in New south Wales: Current pH values and estimates of acidification rates. Australian Journal of Soil Research. 1990, 28: 52337

Hochmuth, G., Maynard, D., Vavrina, C., Hanlon, E. and Simonne, E. C., 2004. Plant Tissue Analysis and Interpretation for vegetable crops in Florida. University of Florida. Cooperative Extension Service, Institute of Food and Agricultural Sciences. http://edis.ifas.ufl.edu/Body_EP081. pp 1- 72 Downloaded on 22 ${ }^{\text {nd }}$ of May, 2004.

Kajisa, K., Maredia, M. and Boughton, D., 1997. Transformation versus stagnation in the oil industry: a comparison between Malaysia and Nigeria. February 1997. Department of Agricultural Economics, Michigan State University. Staff paper. 97-5

Ma, A. N., Chean, S. A. and Chow, M. C., 1993. Current status of palm oil processing waste management. I. N.: Waste Management in Malaysia: Current Status and Prospects for Bio degradation, B. G. Yeoh et al., (Eds.), pp. 111-136.

Mehlich, A. 1984. Mehlich 3 soil test extractant: A modification of the Mehlich 2 extractant. Communication of Soil Science and Plant Analysis. 15(12): 1409-1416.

Mengel, K and Kirkby E. A., 2001. Principles of Plant Nutrition, 5th Edition. Kluwer Academic Publishers, Netherlands. pp 1-110

Mutert, E. W. and Fairhurst, T. H., 1999. Oil palm - the great crop of south East Asia: Potential, nutrition and management. Potash \& Phosphate Institute http://www.fertilizer.org/ifa/publicat/PDF/1999_biblio_45.pdf

NIFOR., 1972. Nigerian Institute for Oil Palm Research, 8th Annual report, 1971/72.

NIFOR., 1973. Nigerian Institute for Oil Palm Research, $9^{\text {th }}$ Annual report, 1972/73.

Ogunremi, L. T., 1977. Incubation studies of potassium fixation and establishing a relationship between chemical test for $K$ and need for fertilization on selected soils from Southern Nigeria. B.Sc. Project. Department of Agronomy, University of Ibadan, Ibadan, Nigeria. Unpublished.

Onwubuya, I. I., 1982. In preliminary trials on the fertilizer requirements of the Poly bag Oil Palm (Elaeis guineensis) seedlings. Journal of Nigeria Institute of Oil Palm Research. 6: No.22, pp $205-215$.

Phicot, J., Sedogo, M. P. and Arrivers, H.F., 1981. Evolution De La Fertilite D'un sol Ferrugineux Tropical Sous L'influence De Femures Milnerales et Organiques. L'Agronomic Tropicale, 36(2) 1981. pp 122-133

Simonne, E. H., McCrimmon, J. N., Scoggins-Mantero, H. L., Mills, H. A. and Cresman, C. P., 1995. In Adjustments of sufficiency ranges of selected ornamentals and turf grasses for assessing nitrogen status with Dumas-N data. Communications in Soil Science and Plant Analysis. , 26: 2243-2251.

Sobulo, R.A., Fayemi, A. A., and Agboola, A. A., 1975. Nutrient requirement of tomatoes (Lycopersion esculentum) in S.W. Nigeria 11 foliar analysis for assessing N, P and K requirements. Experimental Agriculture. Vol. II: 137-143

Thambirajah, J .J, Zulkifli, M .D. and Hashim, M.A., 1995. Microbiological and biochemical changes during the composting of oil palm empty bunch; effect of nitrogen supplementation on the substrate. Bio resource Technology 52: 133 - 144.

von Uexkull, H. R.., 1992. Oil Palm (Elaeis guineensis Jacq.). In IFA World Fertilizer Use Manual. Pp 245-253.

Wieder, R. K. and Lang G. E., 1982. A critique of the analytical method used in examining decomposition data obtained from litter bags. J. Ecology 63: 1636-1642

Yusri, A., Rasol, M., Mohammed, O., Azizah, H., Kume, T., and Hashimoto, S., 1995. Biodegradation of oil palm empty bunch into compost by composite micro-organisms. Paper presented at the EU-ASEAN Conf. Combustion of solid and treated product. Pp 8-9. 
Lim, K. C. and Zaharah, A. R. 2000. Decomposition and N and K Release by Oil palm Empty Fruit Bunches Applied Under Mature Oil palm. Journal of Oil palm Research. 12(2): 55-60.

\section{Author Biography}

Olugbenga O. AdeOluwa (PhD) majors in Soil Fertility and Organic Agriculture. He is a DAAD, SIDA, MASHAV and USDA fellow. His present research focuses on nutrient recycling and conversion of organic materials into fertilizer. 